\title{
Acute Intervillous Thrombus
}

National Cancer Institute

\section{Source}

National Cancer Institute. Acute Intervillous Thrombus. NCI Thesaurus. Code C117327.

A focus of maternal thrombus within the placental intervillous space, often with peripheral villous compression, which is less than 1-2 days in age. 